\title{
Trygg trafikk
}

I Norge har vi skiftende vær- og føreforhold, og det går vei til de mest utilgjengelige steder. Mer enn 2,6 millioner nordmenn har førerkort, det er 5,2 millioner biler med norske skilter og det kjøres 45 milliarder kilometer hvert år (1). I fjor ble likevel kun 117 personer drept og 693 skadet på norske veier (1). Til sammenlikning var det samlede tallet over seks ganger så høyt i 1970 (1). Denne nedgangen speiler i hovedsak den systematiske innsatsen fra ulike aktører innen trafikksikkerhetsarbeidet, i mindre grad bedre prehospitale tjenester og spesialisert traumebehandling i sykehus (2). De fleste enkle og mest effektive tiltak er nok allerede gjennomført og nullvisjonen er kanskje urealistisk, men dødsfall og skader i trafikken rammer fortsatt i for stor grad enkeltmennesker, familier og samfunnet til at vi kan si oss fornøyd.

I dette nummer av Tidsskriftet skriver Anders Holtan om legers viktige og dels neglisjerte rolle i forebygging av trafikkulykker (3). Vi skjøtter vår nøkkelrolle i skadebehandlingen godt, men har også et stort ansvar når det gjelder forvaltning av helsekrav til førerkort, pasienters bruk av rusmidler og trafikkfarlige legemidler samt rekvirering av obduksjoner. Holtan trekker også frem betydningen av legers deltagelse $\mathrm{i}$ forskning på trafikkulykker og poengterer med rette at dette ikke har vært noe prioritert område for offentlig forskningsstøtte. I kjølvannet av regjeringens ferske stortingsmelding som kun handler om trafikksikkerhet - faktisk den første på nesten 30 år - er det håp om at vi kan se en økende interesse for forebyggende helsearbeid og forskning på dette feltet (1).

I et globalt perspektiv står dessverre den positive utviklingen i Norge og andre høyinntektsland i kontrast til det økende antallet trafikkulykker i lavinntekts- og middelinntektsland (4). Selv om disse landene kun har $50 \%$ av bilene i verden, står de for over $90 \%$ av alle trafikkdødsfall (4). Dette gjelder spesielt land med rask økonomisk vekst, som Brasil, Russland, India, Kina og flere land i Afrika (5). Til tross for en stadig økende biltrafikk har de store mangler i trafikksikkerhetsarbeidet, og det er utrygt på veiene for både fotgjengere og bilførere (4). Samtidig har de fleste av disse landene også betydelige svakheter i prehospitale tjenester, sykehusbehandling, rehabilitering, kvalitetskontroll og forskning (6).

Globalt ble det i fjor registrert om lag 1,5 millioner dødsfall i trafikken, noe som tilsvarer drøyt 4000 hver dag (5). Omtrent 50 millioner mennesker blir hvert år skadet (4). De reelle tallene er trolig enda høyere, ettersom man i flere land har begrenset oversikt over ulykkene (6). På verdensbasis er trafikkulykker den viktigste dødsårsaken i aldersgruppen 15-29 år (4). Hvis utviklingen fortsetter, vil dette være den femte vanligste dødsårsaken innen 2030 (4). FN har derfor inkludert trafikksikkerhet i to av sine 17 mål for bærekraftig utvikling i verden (7).
Norske leger kan bidra med mye for å redusere omfanget av trafikkskader her i landet, men vi kan også gjøre en innsats i andre land. For eksempel har nevrokirurger fra Bergen over flere år vært engasjert i utdanning og oppbygging av en bærekraftig nevrokirurgisk avdeling i Etiopia, der det er mange alvorlige trafikkskader. I et pågående forskningsprosjekt skal vi undersøke behandlingen av hode- og ryggmargsskader og belyse konkrete satsingsområder for forebyggende helsearbeid innen blant annet trafikksikkerhet. I Etiopia er det begrensede behandlingsressurser, og det er ikke mulig å overføre direkte kunnskapsbaserte retningslinjer som vi i Norge opererer med (7). Likevel vil dette prosjektet kunne gi viktig informasjon om kvaliteten av behandlingen og gi føringer for tilpassede retningslinjer. I tillegg kan vi kanskje lære noe om våre egne rutiner - det er ikke alltid slik at våre selvsagte og mer ressurskrevende måter å gjøre ting på, kommer pasientene så mye til gode som vi tror $(8,9)$.

\section{Terje Sundstrøm}

tjsu@helse-bergen.no

Terje Sundstrøm (f. 1977) er ph.d., overlege i nevrokirurgi ved Haukeland universitetssykehus, medlem av Scandinavian Neurotrauma Committee og forsker ved Institutt for biomedisin, Universitetet i Bergen.

Forfatter har fylt ut ICMJE-skjemaet og oppgir ingen interessekonflikter.

\section{Litteratur}

1. Meld. St. 40 (2015-2016). Trafikksikkerhetsarbeid - samordning og organisering

2. Stein SC, Georgoff $P$, Meghan $S$ et al. 150 years of treating severe traumatic brain injury: a systematic review of progress in mortality. J Neurotrauma 2010; 27: $1343-53$

3. Holtan A. Forebygging av trafikkulykker - helsepersonell har en rolle. Tidsskr Nor Legeforen 2016; 136: 1900-2.

4. Global status report on road safety 2015. Genève: WHO, 2015

5. GBD 2015 Mortality and Causes of Death Collaborators. Global, regional, and national life expectancy, all-cause mortality, and cause-specific mortality for 249 causes of death, 1980-2015: a systematic analysis for the Global Burden of Disease Study 2015. Lancet 2016; 388: 1459-544.

6. Rubiano AM, Carney N, Chesnut R et al. Global neurotrauma research challenges and opportunities. Nature 2015; 527: S193-7.

7. Resolution 70/1. Transforming our world: the 2030 Agenda for Sustainable Development. New York: United Nations General Assembly, 2015. https://sustainabledevelopment.un.org/post2015/transformingourworld (8.11.2016).

8. Hauswald M, Ong G, Tandberg D et al. Out-of-hospital spinal immobilization: its effect on neurologic injury. Acad Emerg Med 1998; 5: $214-9$.

9. Chesnut RM, Temkin N, Carney N et al. A trial of intracranial-pressure monitoring in traumatic brain injury. N Engl J Med 2012; 367: 2471-81. 